\title{
Note from the President
}

Published online: 14 September 2020

(c) Society for Biological Inorganic Chemistry (SBIC) 2020

\section{The Society of Biological Inorganic Chemistry}

SBIC has been established as a learned society of advanced research and education in the field of Biological Inorganic Chemistry

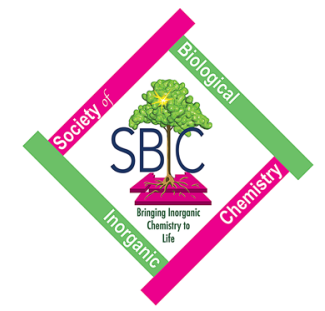

\section{SBIC COUNCIL}

\section{SBIC Officers}

\section{President}

Sue Berners-Price, Brisbane, Australia

Past President

Michael Hannon, Birmingham, UK

President Elect

Vincent Pecoraro, Michigan, USA

Secretary

Christian Hartinger, Auckland, NZ

Treasurer

Charles Riordan, Newark, DE, USA

\author{
SBIC Council Members \\ Paul Donnelly, Melbourne, Australia \\ Oliver Einsle, Freiburg, Germany \\ Kazuya Kikuchi, Osaka, Japan \\ Elizabeth Nolan, Cambridge, USA \\ Clotilde Policar, Paris, France \\ Hongzhe Sun, Hong Kong \\ Liliana Quintanar, Mexico City, Mexico \\ Deborah Zamble ${ }^{\dagger}$, Toronto, Canada
}

JBIC Chief Editor

Nils Metzler-Nolte, Bochum, Germany

Program Committee/ICBIC-IOC

Roland Sigel, Zurich, Switzerland

Nominations Committee

Chair: Alison Butler, Santa Barbara, USA

Norah Barba-Behrens, Mexico City, Mexico

Peng Chen, Beijing, China

Peter Faller, Strasbourg, France

Sigríour Guorún Suman, Reykjavik, Iceland

Yoshi Watanabe, Nagoya, Japan

Society Honorary Members

Harry Gray, Pasadena, CA, USA

Richard Holm, Cambridge, MA, USA

Bernhard Lippert, Dortmund, Germany

Jan Reedijk, Leiden, The Netherlands

Helmut Sigel, Basel, Switzerland

Karl Wieghardt, Mülheim an der Ruhr,

Germany
Dear SBIC Members and JBIC Readers,

What a difficult year this has been for all of us in adjusting to a world impacted by the COVID-19 pandemic. I was hoping to catch up with many of you as we looked forward to three important BIC conferences in 2020, with Eurobic-15 planned to be held in Reykjavik, Iceland in August; LABIC-VII in Montevideo, Uruguay in September; and ASBIC-10 in Guilin, China in October. Instead, there will be a virtual EuroZoom in two sessions on 17 and 18 August online; LABIC has been postponed to April 2021; and AsBIC10 has been cancelled, with the next AsBIC conference to take place in Nara, Japan in 2022.
As there are no face-to-face meetings for us to drum up support for article submissions, please show your loyalty to our community, and to SBIC, by submitting your best work to JBIC. In this respect, I am pleased to advise that SBIC has reached agreement with Springer Nature to continue to publish JBIC for a further 5-year period from 2021. Under the leadership of Editor-in-Chief Nils Metzler-Nolte, we will work hand-in-hand with Springer Nature to further develop JBIC as the premier journal covering all fields of bioinorganic chemistry, including new challenges and developments such as nanotechnology and modern systems biology. 
Many congratulations to Professor Liviu Mirica, the recipient of the 2020 SBIC Early Career Award. Liviu has established a broad research program in the areas of biological inorganic chemistry, chemical biology, and bioinspired organometallic chemistry at the University of Illinois at Urbana-Champaign.

Finally, it is with most profound sadness that I note the recent passing of Professor Deborah Zamble of the University of Toronto, who provided great service to our community, including as a current member of the SBIC Council. Deborah was an outstanding scientist, recognised for her research on the role of nickel in biological processes, and especially on nickel homeostasis in bacteria. She was also a really lovely person and for both these reasons, she will be very much missed by the biological inorganic chemistry.

With best wishes

Sue Berners-Price

Gold Coast, Australia

August 2020

Publisher's Note Springer Nature remains neutral with regard to jurisdictional claims in published maps and institutional affiliations. 